\title{
AN UNUSUAL CASE OF PARACOCCIDIOIDOMYCOSIS IN BRAZIL
}

\author{
Danielle Patrícia Cerqueira Macêdo ${ }^{1}$ * Rejane Pereira Neves ${ }^{1}$; Oliane Maria Correia Magalhães ${ }^{1}$; \\ Armando Marsden Lacerda Filho ${ }^{1}$
}

\begin{abstract}
${ }^{1}$ Departamento de Micologia, Centro de Ciências Biológicas, Universidade Federal de Pernambuco, Recife, PE, Brasil.
\end{abstract}
Submitted: January 03, 2006; Returned to authors for corrections: April 17, 2006; Approved: October 13, 2006

\begin{abstract}
This paper reports an unusual case of paracoccidioidomycosis with ulcerations in the head and nose in a Brazilian man. For diagnosis, direct microscopic examination of ulcer secretion and skin samples treated with potassium hydroxide was performed. The isolation of Paracoccidioides brasiliensis occurred at $28^{\circ} \mathrm{C}$ and $37^{\circ} \mathrm{C}$ on Sabouraud agar with chloranphenicol. Diagnosis was established by the presence of isolated and multiple budding yeast-like cells and typical fungus growth of $P$. brasiliensis.
\end{abstract}

Key words: Paracoccidioidomycosis, Paracoccidioides brasiliensis, unusual head lesion

Paracoccidioidomycosis is one of the most important systemic mycosis affecting residents of tropical and subtropical regions in Latin America (3,5). The etiological agent is the dimorphic fungus Paracoccidioides brasiliensis, which occurs in the filamentous form in nature, and the disease is thought to be acquired by inhalation of the propagules produced by this phase. The most common way of penetration in human body is through the lungs, with later lymph-hematogenic dissemination to other organs, skin or mucosas: buccal, pharyngeal, intestinal and rarely by inoculation into the skin (2). Clinical manifestations range from asymptomatic pulmonary lesions to generalized systemic infections $(1,7,8,11)$.

We present an unusual case of paracoccidioidomycosis diagnosed in Brazil. In June 2005, a 47-year-old Brazilian man arrived in the Sector of Pneumology at Otávio Freitas hospital in Recife state of Pernambuco, in Northeast of Brazil, with a suspect of tuberculosis and history of swellings and ulcerations of his nose and head (Fig. 1). Several months before, he had presented chronic bronchitis with fever episodes. A chest X ray revealed bilateral, diffuse pulmonary infiltrates. Skin lesions were painful and the patient was physically and psychologically handicapped, and clinical symptoms included occasional night sweats. No acid-fast bacilli or malignant cells were detected during exams.
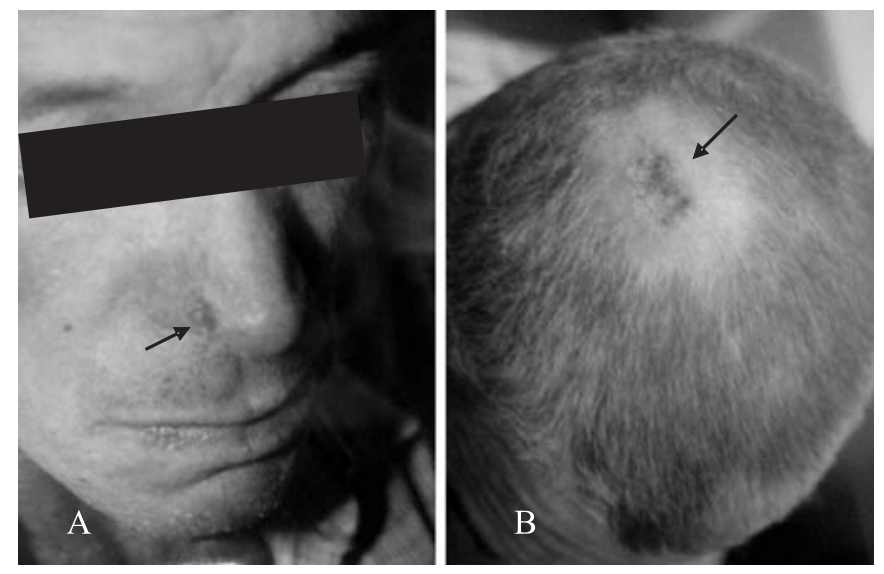

Figure 1. A) Lesion on nose and B) granulomatous lesion of the head caused by Paracoccidioides brasiliensis.

Clinical samples were processed at Medical Mycology Laboratory, Federal University of Pernambuco. Direct examination was performed after clarification of the sample fragments with $20 \%$ potassium hydroxide solution. For isolation, the samples were inoculated on the surface of Sabouraud agar with $50 \mathrm{mg}$ chloranphenicol/L, and incubated at room temperature

*Corresponding Author. Mailing address: Rua José Paraiso, 135/01 Boa Viagem cep 51030-390 Recife, PE - Brasil. Tel.: (81) 2126-8482. E-mail: rejadel@yahoo.com.br 
$\left(28^{\circ} \pm 2^{\circ} \mathrm{C}\right)$ and $37^{\circ} \mathrm{C}$ during 20 days. The identification was done according to Lacaz et al. (6).

The examination of ulcer secretion and skin samples indicated presence of multiple budding which are diagnostic criteria for paracoccidioidomycosis (Fig. 2). Cultures incubated at $37^{\circ} \mathrm{C}$ were cream-colored yeast-like wrinkled colonies. Cells presented double refractile wall, were birefringent and presented multiple budding of $P$. brasiliensis. At room temperature a mould with short aerial hyphae could be observed. Physicians prescribed a ketoconazole (200 mg/day) therapy. After three weeks, the lesions and pulmonary infiltrates had disappeared almost completely and the patient was discharged, but treatment was continued for additional five months.

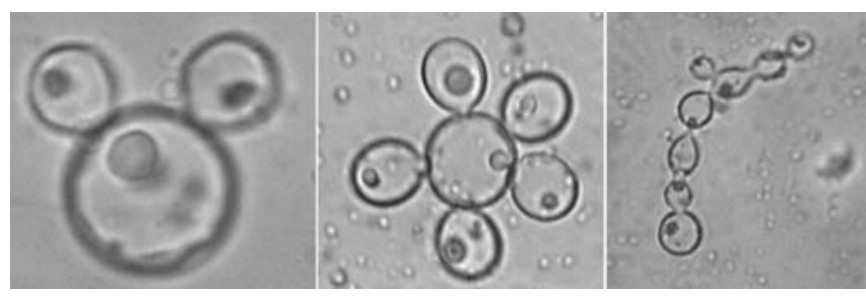

Figure 2. Yeast form seen at direct examination. Note the "Mickey Mouse type", "pilot wheel" and catenulate forms of Paracoccidioides brasiliensis.

Although unusual or atypical aspects of the disease may be observed in adult patients lesions circumscribed to the lung are seen in $20-40 \%$ of then (9). Pulmonary and skin lesions have been commonly suspected to be tuberculosis, and diagnosis confirmed this (10). Respiratory symptoms may be non-specific, as occurred with the patient of this report. The chronic multifocal form is frequently characterized by pulmonary involvement and mucocutaneous lesions, predominantly in the oral and nasal cavities (5), which were not observed in the head deep lesions of the patient. According to Elias et al. (4) the involvement of the central nervous system in paracoccidioidomycosis is higher than previously thought.

Although ulcerative lesions in head are rare, this diagnosis should be considered as an important sign of this mycosis. Patients with early diagnosis have a favorable outcome with clinical or surgical treatment.

\section{RESUMO}

\section{Um caso incomum de paracoccidioidomicose no Brasil}

Este trabalho relata um caso incomum de paracoccidioidomicose com ulcerações na cabeça e nariz em homem brasileiro. Para o diagnóstico, realizou-se exame microscópico direto de secreção de úlcera e amostras de pele, tratados com hidróxido de potássio. O isolamento de Paracoccidioides brasiliensis ocorreu a $28^{\circ} \mathrm{C}$ e $37^{\circ} \mathrm{C}$ em Sabouraud ágar com cloranfenicol. O diagnóstico foi estabelecido pela presença de células leveduriformes isoladas e com brotações múltiplas e o crescimento típico do fungo $P$. brasiliensis.

Palavras-chave: Paracoccidioidomicose, Paracoccidioides brasiliensis, lesão incomum em cabeça

\section{REFERENCES}

1. Brummer, E.; Castaneda, E.; Restrepo, A. (1993). Paracoccidioidomycosis: an update. Clin. Microbiol. Rev., 6, 89-117.

2. Burnier, S.V.; Sant'Anna, A.E. (1997). Palpebral paracoccidioidomycosis. Mycopathologia, 140, 29-33.

3. Cadavid, D.; Restrepo, A. (1993). Factors associated with Paracoccidioides brasiliensis infection among permanent residents of three endemic areas in Colombia. Epidemiol. Infect., 111, 121133.

4. Elias, J.J.; Santos, A.C.; Carlotti, C.G.; Colli, B.O.; Canheu, A.; Matias, C.; Furlanetti, L.; Martinez, R.; Takayanagui, O.M.; Sakamoto, A.C.; Serafini, L.N.; Chimelli, L. (2005). Central nervous system paracoccidioidomycosis: diagnosis and treatment. Surgical Neurology, 63, 13-21.

5. Horré, R.; Schumacher, G.; Alpers, K.; Seitz, H.M.; Adler, S.; Lemmer, K.; Hoog, G.S. de; Schaal, K.P.; Tintelnot, K. (2002). A case of imported paracoccidioidomycosis in a German legionnaire. Med. Mycol., 40(2), 213-216.

6. Lacaz, C.S.; Porto, E.; Heins-Vaccari, E.M.; Melo, N.T. (1998) Guia para Identificação de Fungos, Actinomicetos e Algas de Interesse Médico. Sarvier, São Paulo, SP.

7. Puccia, R.; Carmona, A.K.; Gesztesi, J.L.; Juliano, L.; Travassos, L.R. (1998). Exocellular proteolytic activity of Paracoccidioides brasiliensis: cleavage of components associated with the basement membrane. Med. Mycol., 36, 345-348.

8. San-Blas, G.; Nino-Veja, G.; Iturriaga, T. (2002). Paracoccidioides brasiliensis and paracoccidioidomycosis: molecular approaches to morphogenesis, diagnosis, epidemiology, taxonomy and genetics. Med. Mycol., 40, 225-242.

9. Santos, J.W.A.; Severo, L.C.; Porto, N.S. (1998). Fine needle aspiration in the diagnosis of pulmonary paracoccidioidomycosis. Mycopathologia, 143, 65-69.

10. Silletti, R.P.; Glezerov, V.; Schwartz, I.S. (1996). Pulmonary paracoccidioidomycosis misdiagnosed as Pneumocystis pneumonia in a immunocompromised host. J. Clin. Microbiol., 34(9), 23282330 .

11. Wanke, B.; Londero, A.T. (1994). Epidemiology and paracoccidioidomycosis infection. In: Franco, M.; Da Silva-Lacaz, C.; Restrepo, M.A.; Del Negro, G. (eds). Paracoccidioidomycosis. CRC Press, Boca Raton, Fla, p.109-120. 